\title{
The effects of the transplantation of thymus-derived multipotent stromal cells on the immune system and survival of lethally irradiated mice
}

\author{
Nikolska K. I. \\ State Institute of Genetic and Regenerative Medicine National Academy of Medical Sciences of Ukraine, Kyiv, Ukraine \\ e-mail: nikolskaya.kiev@gmail.com
}

\section{ABSTRACT}

The traditional source for regeneration of the immune system is hematopoietic stem cells. Multipotent stromal cells (MSCs), especially MSCs of the thymus, have been significantly less studied for this purpose.

THE AIM was to study the regenerative, immunobiological and radioprotective properties of thymus-derived multipotent stromal cells.

MATERIALS AND METHODS. Researches were conducted to study the effect of transplantation of thymus-derived MSCs on the survival and features of restoration of the immune system of lethally irradiated mice. Lethally irradiated (with dose 9 Gy) CBA mice, 5-6 weeks old, were injected intravenously with $5 \cdot 10^{4}$ thymus-derived MSCs. On the $30^{\text {th }}$ day the cellularity of lymphoid organs, bone marrow and blood, natural and adaptive immunity were studied.

RESULTS. It was found that transplanted thymus-derived MSCs significantly prolonged the survival and average lifespan of mice, restored the cellularity of bone marrow, the ability of bone marrow stromal cells to form fibroblast colonies, greatly increased the cellularity of the thymus and contributed to the normalization of the number of leukocytes in the blood. In addition, the natural cytotoxic activity of splenocytes and their ability to synthesize $\alpha / \beta$ - and $\gamma$-interferons, significantly increased, the number of antibody-producing cells was stimulated and the synthesis of antibodies increased. The concentration of the tumor necrosis factor a in the blood was significantly reduced.

CONCLUSIONS. The results indicate that thymus-derived MSCs possess pronounced regenerative and immunobiological activity, which provides these cells with radioprotective ability. The obtained data can be used to develop combined cell transplants and new methods for improving their regenerative potential and radioprotective effects.

KEY WORDS: thymus-derived multipotent stromal cells; cell transplantation; regeneration of the immune system; lethal irradiation

Hematopoietic stem cells (HSCs), which under physiological conditions are a heterogeneous population of cells of varying degrees of maturity, are precursors to all cells of the immune system, except for stromal ones. They constitute in general a well-known continuum of HSCs and their progenitors whose elements differ fundamentally in the range of multipotency and sensitivity to humoral and intercellular contact regulation [1]. Transplantation of HSCs and progenitors to irradiated animals provides restoration of the immune system and protects them from the development of the lethal bone marrow failure syndrome. But sometimes the results are not quite satisfactory and the question arises whether this is due to insufficient number of HSCs in cell transplant as well as multipotent stromal cells (MSCs), which usually perform an important function of supporting HSCs in bone marrow niches [2, 3]. Particularly noteworthy is that in transplants of bone marrow cells one can expect the presence of a certain number of bone marrow MSCs and they do not contain thymic MSCs at all. Meanwhile, the thymus-derived MSCs differ significantly in properties from bone marrow-derived, bone and dermal subpopulations of MSCs and are unique.

The study of cell markers on models of transgenic animals has shown that the mesenchyme around the thymus originates from the neural crest [4]. Mesenchymal cells play an active role in the formation of embryonic and adult thymus $[5,6]$, and they play an essential role in the positive selection and migration of T-lymphocytes [7]. Especially thymus MSCs stimulate the development of double-negative CD4-CD8 cells in the thymus $[8,9,10]$. 
In the embryogenesis, thymic MSCs regulate the proliferation of thymic epithelial cells, producing fibroblast growth factors (FGF) 7 and 10, insulinlike growth factor (IGF) type 1 and 2, and retinoic acid [9, 11, 12, 13, 14]. In adult thymus, CD148 ${ }^{+}$MSCs are involved in revascularization and thymus regeneration after infection, producing fibroblast-specific protein-1 (FSP 1) required to support the thymus medullar epithelium $[15,16]$.

Significant differences between MSCs of the thymus, bone and dermis, highlighting the importance of functional activity of thymic MSCs, were revealed with transcriptome analysis [17]. In this paper, the selection of cells for research was based on the authors' opinion that the properties of MSCs may depend on the microenvironment. Therefore, MSCs of the thymus and dermis should have mechanisms to support epithelial cells, and MSCs of the thymus and bone have a positive effect on hematopoietic cells. In all three populations, 6270 genes that provide housekeeping were found, 2850 core ones and 2036 differentially expressed genes (DEGs), whose expression often 5 -fold varied in three populations, indicating cell heterogeneity. DEGs were associated with characteristic functions: elimination of apoptotic cells (thymus-derived MSCs), osteoclastogenesis (bone-derived MSCs) and support of hair follicles (dermal MSCs). Higher expression of DEGs in thymic MSCs provides regulation of chemotaxis and polarization of M2 macrophages that contribute to antiinflammatory processes. Three DEGs are involved in the attracting and expanding hematopoietic thymocytes precursors. They expressed in thymic MSCs on the highest level. DEGs of both thymus and bones were also expressed in an increased number of five genes, which contributed to the expansion of hematopoietic precursor cells and were poorly expressed in MSCs of dermis or thymocytes. In addition, out of the 25 main DEGs that were expressed in MSCs of the thymus and dermis, 7 were encoded by molecules that participated in the adhesion of epithelial cells to the basement membrane and signaling during mesenchymal-epithelial transition. The considered data indicate the heterogeneity of MSCs of different tissue origin. The main functions of the thymic MSCs are to promote efferocytosis, support for hematopoietic progenitor cells and epithelial cells [17].

The obtained data testify to the possible active impact of thymic MSCs on regeneration of thymus and T cell-mediated immunity, which was first showed in our previous studies [18].

The purpose of our work is to study the effects of thymus-derived MSCs on the regeneration of the immune system of lethally irradiated mice.

\section{MATERIALS AND METHODS}

The work was performed on 113 CBA male mice, 5-6 weeks old, the in compliance with the requirements of Article 26 of the Law of Ukraine

\section{Primary culture of murine thymus-derived MSCs}

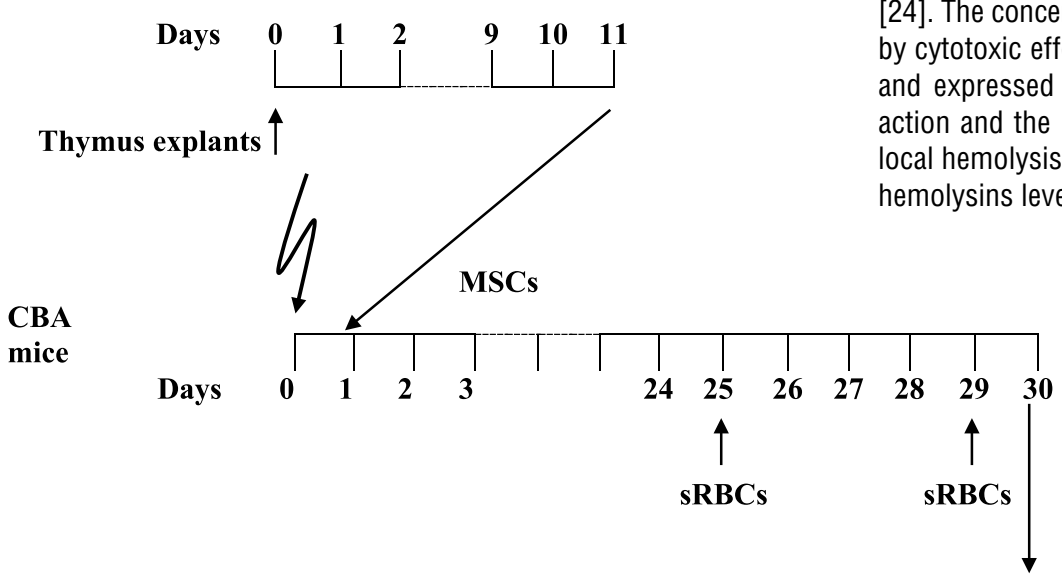

Survival on the $30^{\text {th }}$ day

Immune system function
«On the Protection of Animals from Cruelty» (February 21, 2006) and «European Convention for the Protection of Vertebrate Animals Used for Experimental and Another Scientific Purposes» (Strasbourg, 1986). The animals were irradiated once using a «Teratron» device with a radionuclide ${ }^{60} \mathrm{Co}$. The irradiation dose was $9.0 \mathrm{~Gy}$, the dose rate was $151 \mathrm{cGy} / \mathrm{min}$.

The culture of thymus-derived MSCs was obtained by explant technique in a DMEM/F12 medium with $10 \%$ fetal bovine serum (all - Sigma, USA) in 6-well plates at $5 \% \mathrm{CO}_{2}$. On the 10th day of cultivation, when numerous fibroblast colonies were clearly visible, the medium was removed, colonies of thymus-derived MSCs were trypsinized to obtain a single-cell suspension using trypsin-EDTA solution. The multipotent properties of thymus-derived MSCs are confirmed by their osteo- and adipogenic differentiation potential in our previous studies [19].

Two experiments were carried out. In the first experiment to study survival and average lifespan after irradiation, 5•10 4 thymus-derived MSCs in $0.2 \mathrm{~mL}$ DMEM/F12 medium were transplanted intravenously into retroorbital sinus $(n=16)$. The control were irradiated mice that received culture medium only $(n=14)$. The animals were monitored for 16 weeks, marking the death date of each mouse.

In the second experiment (Fig. 1), to study immune system functions, the following groups were formed: 1 - normal mice $(n=11) ; 2$ - lethally irradiated mice receiving culture medium $(n=32) ; 3$ - lethally irradiated mice receiving thymus-derived MSCs $(n=40)$. Animals were observed for 30 days, fixing the date of death of each mouse. On the $25^{\text {th }}$ day, all animals were immunized by intraperitoneal injection of $10^{8}$ sheep erythrocytes. After 4 days, re-immunization to develop the delayed-type hypersensitivity was performed by the administration of the same amount of red blood cells into the footpad. On the next day (30 days after irradiation), the survival rate of the animals was assessed, and the parameters of the immune system were determined after the decapitation under ether anesthesia. In surviving animals, on the $30^{\text {th }}$ day (5 mice in group two, 8 mice in group three), we determined the absolute and relative weight of the thymus and spleen, the number of thymocytes, splenocytes and bone marrow cells, the number of fibroblast colony forming units (CFU-F) in the bone marrow [20], the number of leukocytes in the peripheral blood. In addition, we counted the leukocyte subpopulations. The phagocytosis activity of peritoneal macrophages with FITC-labeled S. aureus was investigated by a flow cytometry [21], bactericidal activity of peritoneal macrophages - according to the index of stimulation in nitro blue tetrazolium (NBT) test [22], and the natural cytotoxicity of splenocytes to K562 cells, and blast-transformation of lymphocytes from mesenteric lymph nodes - by MTT assay [23]. The content of $\alpha / \beta$ - and $\gamma$-interferons (in $\log _{2}$ titres) induced in the culture of splenocytes by the Newcastle disease virus or $10 \mu \mathrm{g} / \mathrm{mL}$ of concanavalin A (Sigma, USA) were investigated assessing the ability of splenocytes culture supernatant to prevent the development of cytopathogenic effect of the vesicular stomatitis virus in the cell culture [24]. The concentration of tumor necrosis factor a (TNFa) was determined by cytotoxic effect of supernatants of splenocytes cultures on L929 cells and expressed as $\log _{2}$ titre [25]. The delayed-type hypersensitivity reaction and the number of antibody-producing cells in the spleen by the local hemolysis in gel was determined as well as the hemagglutinins and hemolysins levels in the blood serum (in $\log _{2}$ titre) was estimated. 


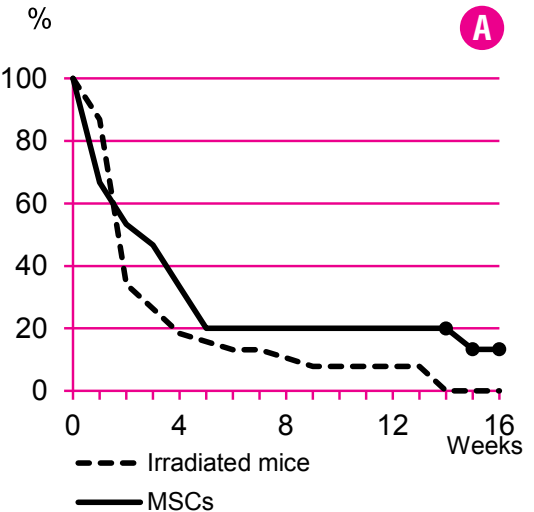

B

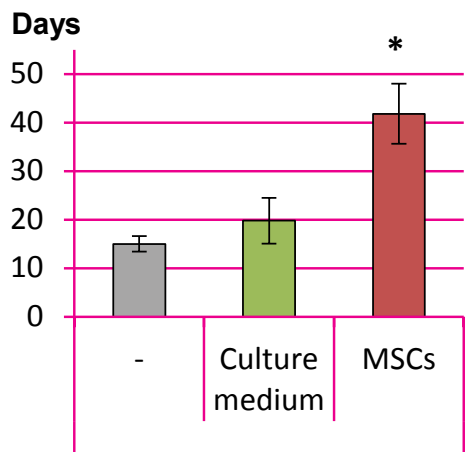

Fig. 2. Survival rate (a) and average lifespan (b) of lethally irradiated mice receiving thymusderived MSCs.

Note: * and $\cdot$ (on the line) $-p<0.05$ compared to only irradiated mice.
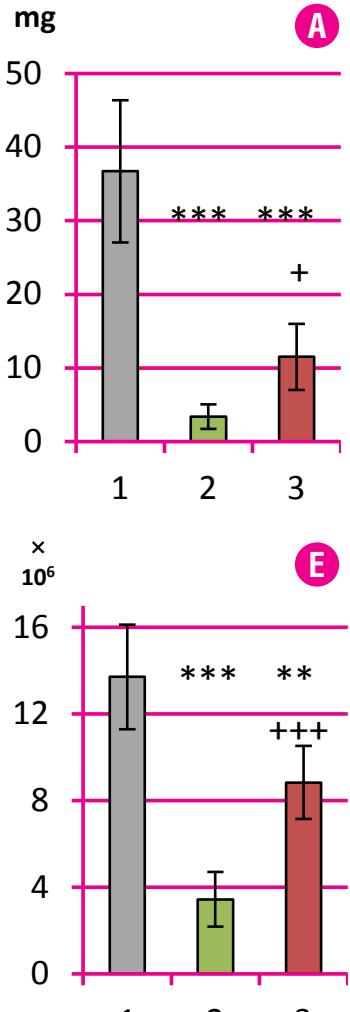

123
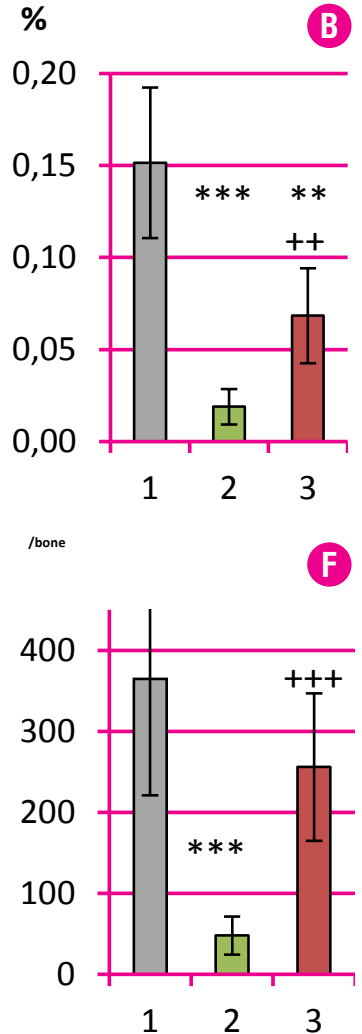

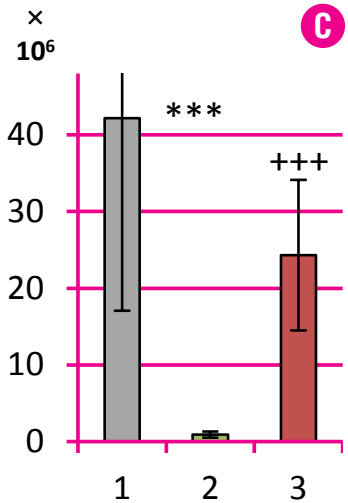

(C)
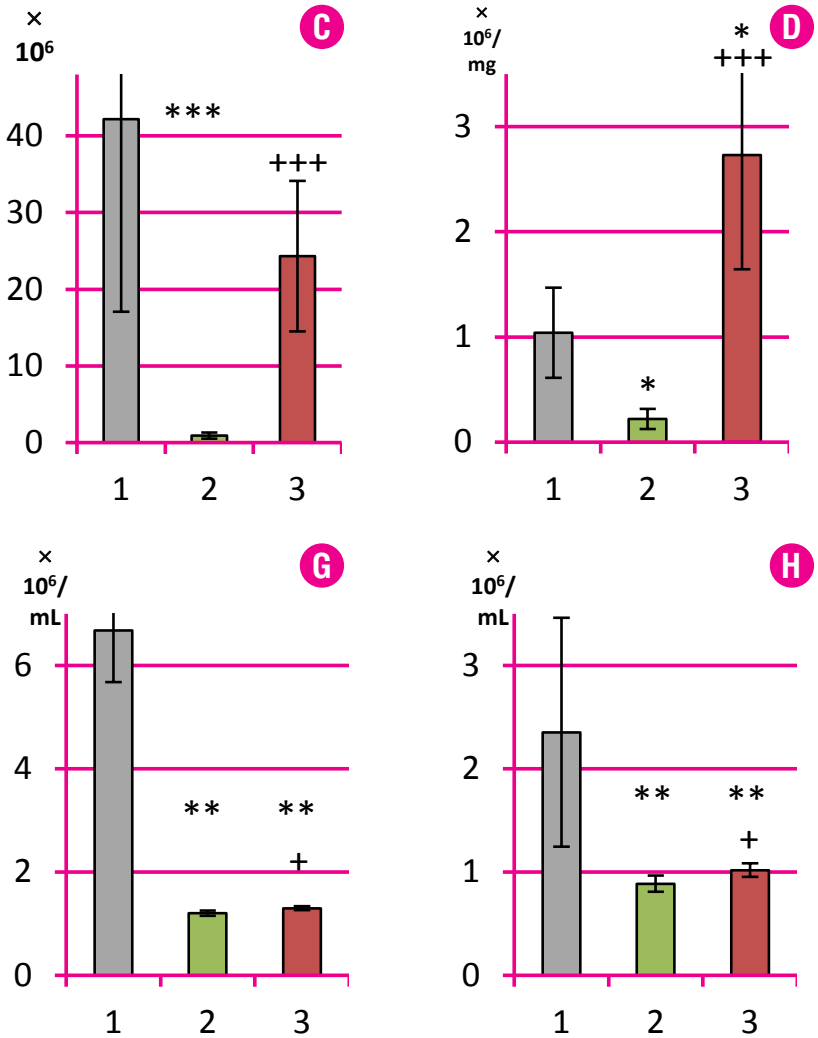

Fig. 3. The weight (a) and the relative weight of thymus (b), the number of thymocytes (c), the cellularity of the thymus (d), the total number of bone marrow cells $(\mathbf{e})$ and CFU-F ( $\mathbf{f})$, the number of leukocytes $(\mathbf{g})$ and neutrophils $(\mathbf{h})$ in peripheral blood. $1-$ normal animals $(\mathrm{n}=11), 2-\mathrm{irradiated}$ animals that received culture medium $(n=5), 3$ - irradiated animals that received MSCs $(n=8)$.

Note: ${ }^{*}-p<0.05,{ }^{* *}-p<0.01,{ }^{* *}-p<0.001$ compared to the group of normal mice; $+-p<0.05,++-p<0.01,+++-p<0.001$ compared to the group of irradiated mice received culture medium.

The obtained results were processed by the methods of variation statistics using MS Office Excel (Microsoft, USA) software. The average lifespan of irradiated mice was determined based on the dynamics of animal death by linear regression using Origin v.6.1 software. The data are presented as mean and standard error of mean $(\mathrm{M} \pm \mathrm{m})$ for each group. The reliability of the differences between the groups was estimated using the Student's t-test, Fischer's exact test, and the non-parametric Mann-Whitney $\mathrm{U}$ test. The critical value of the significance level was considered $\mathrm{p}<0.05$.

\section{RESULTS AND DISCUSSION}

The transplantation of syngeneic MSCs contributed to the increase of survival rates, although, at the level of the trend, almost at all terms of observation (Fig. 2), from the $14^{\text {th }}$ week - significant. At that time, all animals died in the control group of irradiated animals, and in the group of mice receiving MSCs, $13 \%$ of animals survived. Average lifespan after irradiation and MSCs injection was $41.8 \pm 6.2$ days and significantly exceeded average lifespan in control group ( $15.0 \pm 1.6$ days, $p<$ 0.05 ). This is an unexpected result, because MSCs are not differentiated into hematopoietic cells, and the current idea of treating bone marrow failure syndrome is the need for transplantation of hematopoietic stem cells and progenitors, from which all the cells of the immune system can develop.

In the second experiment, the 30-day survival rate of mice receiving thymus-derived MSCs was $20.0 \%$, slightly higher than that of irradiated control mice $(15.6 \%)$, but statistically insignificant $(p>0.05)$, as in the first experiment at this term.

Basic cell-dependent parameters of thymus after irradiation significantly decreased (Fig. 3 A, B, C, D). After the injection of thymus-derived 


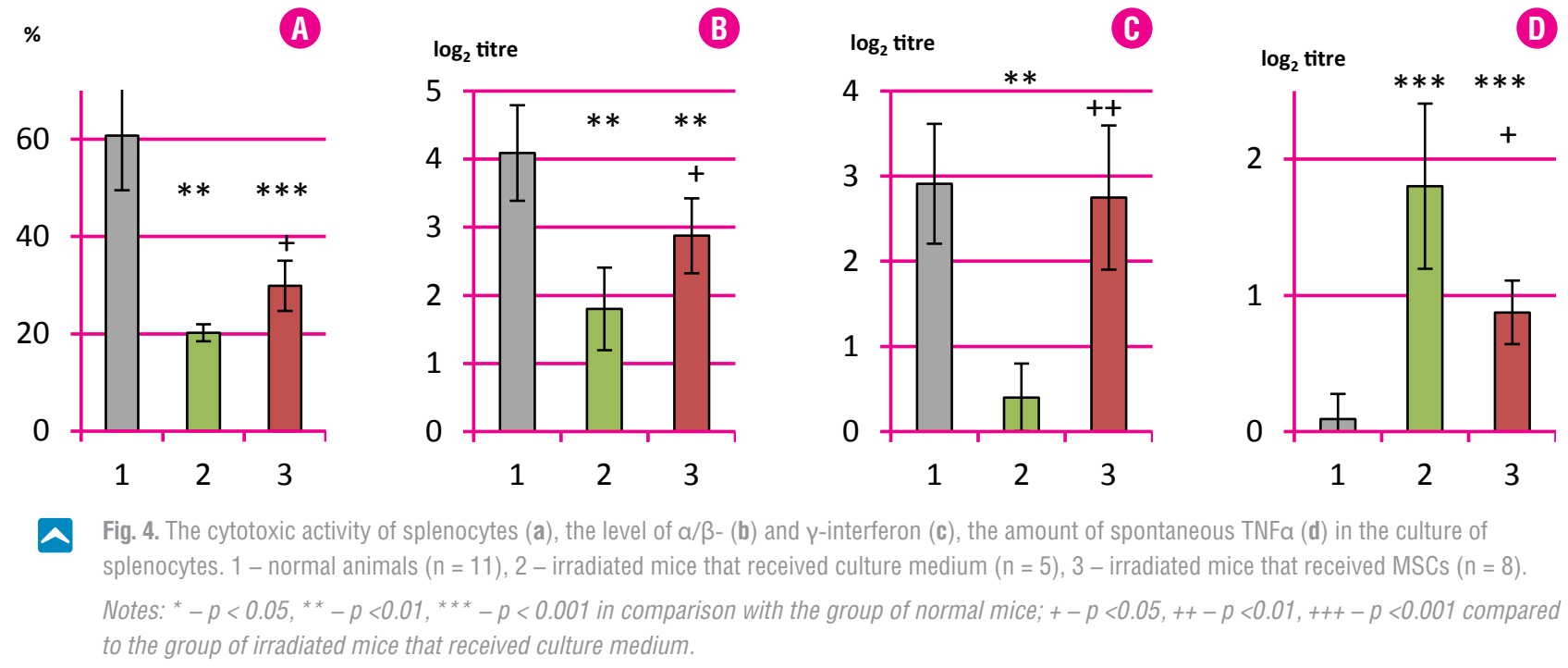

(A)

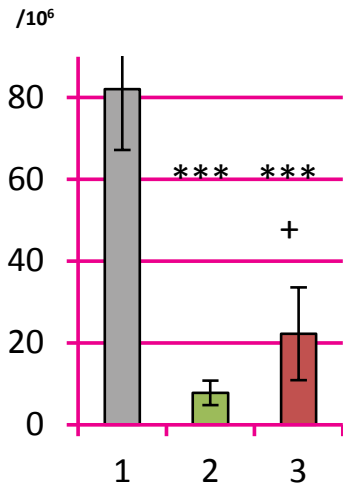

B

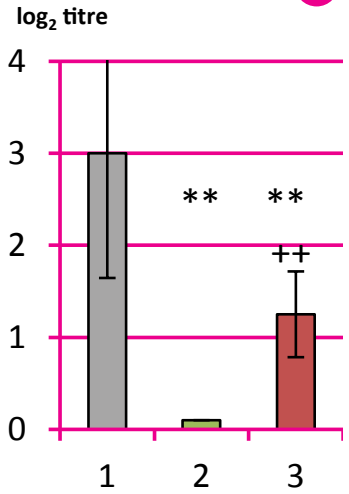

MSCs, the mass of the thymus significantly increased (Fig. 3 A, B), as well as significantly increased the cellularity of the thymus (Fig. $\mathbf{3}$ C, D).

The cellularity of the bone marrow (Fig. $3 \mathrm{E}$ ) and the number of CFU-F (Fig. 3 F) were essentially restored. The number of leukocytes (Fig. $3 \mathbf{~ G}$ ) and neutrophils (Fig. $\mathbf{3} \mathbf{H}$ ) in peripheral blood also significantly increased.

The cytotoxicity of splenocytes (Fig. $4 \mathrm{~A}$ ) and their ability to produce $\alpha / \beta$ - (Fig. 4 B) and $\gamma$-interferons (Fig. 4 C), which play a major role in antiinfective protection and activation of the immune system, significantly increased. The amount of spontaneous TNFa in the culture medium of the splenocytes culture was significantly reduced after injection of MSCs (Fig. 4 D). This finding may indicate a decrease in the number of TNFinducing infectious factors penetrating from the affected intestinal barrier, especially as TNFa demonstrates the radioprotective effects only in the early period following irradiation [26].

The number of antibody-producing cells in spleen significantly increased (Fig. $\mathbf{5 ~ A ) . ~ A l s o , ~ i n ~ t h e ~ b l o o d ~ s e r u m , ~ t h e ~ l e v e l ~ o f ~ h e m a g g l u t i n i n s ~}$ (Fig. 5 B) and hemolysins increased significantly (Fig. 5 C).

In other tests, MSCs transplantation did not change the absolute and relative weight of the spleen, the total number of splenocytes, phagocytosis and bactericidal activity of peritoneal macrophages, the reaction of blast transformation of the lymphocytes of the mesenteric lymph nodes, the delayed-type hypersensitivity reaction.

Thus, the performed studies found out that transplantation of thymus-derived MSCs to lethally irradiated mice stimulates the regeneration of the immune system and common radioprotective ability.

Contrary to constant conception that the main mechanism of MSCs impact in vitro is antiproliferative effects [27], at thymus-derived MSCs transplantation in mice receiving cyclophosphamide, there was a rege-

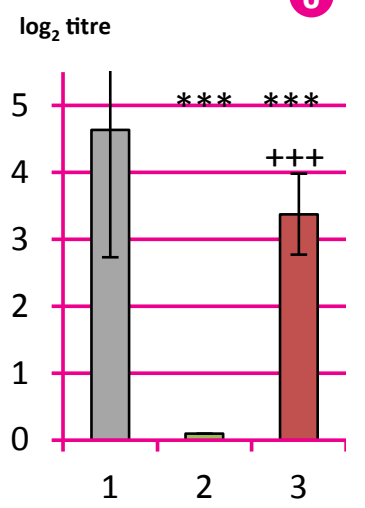

Fig. 5. Number of antibody-producing cells per $10^{6}$ splenocytes (a), titer of hemagglutinins (b) and hemolysins (c) in the blood serum. 1 - normal mice $(n=9), 2$ - irradiated mice that received culture medium $(n=5), 3$ - irradiated animals that received MSCs $(\mathrm{n}=11)$. Notes: ${ }^{*}-p<0.05,{ }^{* *}-p<0.01$ $* * *-p<0.001$ compared to the normal mice; $+-p<0.05,++-p<0.01$, $+++-p<0.001$ compared to the group of irradiated mice that received culture medium. neration of the immune system with significant restoration of bone marrow and thymus cellularity and the transition of a large number of lymph node cells from the $G_{0} / G_{1}$ phase into the $S+G_{2} / M$ phase of cell cycle, as shown in our previous work [28].

In irradiated mice, under the impact of transplanted thymus-derived MSCs for the first month, it also largely regenerates the thymus and bone marrow with significant recovery of CFU-F number in bone marrow. Moreover, due to the regeneration of bone marrow myeloid lineage in the blood, the number of leukocytes and neutrophils is significantly increased. There is an evidence that transplanted MSCs are able to migrate to the bone marrow, due to CXCR4 overexpression [29]. In addition, MSCs can suppress the pro-apoptotic processes by positive regulation of the anti-apoptotic proteins Bcl2 and p-Akt and reduction of the proapoptotic protein Bax expression [30]. Contact interaction of MSCs with different cells substantially supports their paracrine effects [31, 32].

The support of the hematopoietic stem cells and progenitors by MSCs plays an important role in the HSCs activity. MSCs is the major cellular component of bone marrow niches of HSCs [2, 3]. MSCs also play an important role in thymus niches, which are involved in the differentiation of thymocytes $[8,9,33,34,35]$. Affinity of MSCs to immature T-cells is known $[7,36]$. It has been shown that MSCs produce exosomes and extracellular microvesicles that effectively support impaired HSCs after irradiation [37]. It can be assumed that the transplanted MSCs partially replace the injured recipient's stromal cells and create a more adequate microenvironment for the homing, proliferation and differentiation of HSCs and progenitors. Most endogenous MSCs are sensitive to irradiation and lose their functionality regardless of tissue origin. Therefore, there can exist an option, when transplanted normal MSCs enhance 
the functioning of the recipient's affected MSCs and promote the proper functioning of the niches for survived HSCs [38, 38, 40]. The radioprotective effect of MSCs can be partly explained by the fact that, in some conditions in vitro, thymus-derived MSCs, but not bone marrow-derived MSCs, stimulate production of antibodies [41]. In vivo, MSCs can also activate antibody production [28, 42].

Another real possibility lies in the recently discovered ability of MSCs to participate in the reactions of innate immunity due to the expression of Toll-like receptors, which may be a mechanism for neutralizing the infection and suppress the bone marrow failure syndrome. MSCs also carry out antiinfectious protection by producing antimicrobial peptides and proteins, as well as extracellular vesicles $[43,44,45]$. There is an evidence that MSCs and myeloid cells functionally co-operate, enhancing the activity of natural immune cells in anti-infective protection [46]. The transplantation of human umbilical cord blood MSCs into irradiated rats has greatly contributed to the regeneration of bone marrow [47] and the immune system as a whole [48]. In addition, MSCs show metabolic and adaptogenic activity, which promotes post-stress regeneration of the immune system [49].

Thus, there are reasons to believe that the immunoregenerative and radioprotective activity of transplanted mesenchymal stromal cells can be realized directly by themselves, or due to their positive differentiation and proliferative effects on hematopoietic stem cells and progenitors.

\section{CONCLUSION}

Thus, as a result of the transplantation of thymus-derived MSCs in lethally irradiated mice, there was an increase of survival and average lifespan, stimulation of the thymus and bone marrow regeneration with the recovery of the production of bone marrow CFU-F. Natural immunity was stimulated: the cytotoxic activity of splenocytes and their ability to produce $\alpha / \beta$ - and $\gamma$-interferons significantly increased and production of TNFa decreased. The number of antibody-producing cells in spleen of irradiated mice after MSCs transplantation significantly increased as well as the ability to synthesize hemolysins and hemagglutinins increased.

The obtained data testify to the effective involvement of transplanted thymus-derived MSCs in the regeneration of the immune system of lethally irradiated mice, which also leads to an increase in common radioprotective ability of the animals. The results can be used to create new combined stem cell transplants and to develop more effective methods for their application.

\section{REFERENCES}

1. Chertkov IL, Gurevich OA. Stvolovaya krovetvornaya kletka i ee mikrookruzhenie [Hematopoietic stem cell and its microenvironment]. Moskva: Meditsina Moscow: Medicine, 1984. 240 p. [In Russian]

2. Nikolskaya El. Kletochnaya kompozitsiya kostnomozgovykh nish gemopoeticheskikh stvolovykh kletok (obzor literatury) [Cell composition of bone marrow hematopoietic stem cells niches (review)]. Zhurnal Natsional'noï Akademiï medichnikh nauk Ukraïni - Journal of National Academy of Medical Sciences of Ukraine. 2015; 21(3-4):272-286. [In Russian]

3. Nikolskaya EI, Butenko GM. Structural-functional organization of the bone marrow hematopoietic stem cells niches. Cell and Organ Transplantology. 2016; 4(1):82-100.

4. Yamauchi Y, Abe K, Mantani A, et al. A novel transgenic technique that allows specific marking of the neural crest cell lineage in mice. Dev. Biol. 1999; 212(1):191203.

5. Conway SJ, Henderson DJ, Copp AJ. Pax 3 is required for cardiac neural crest migration in the mouse: evidence from the splotch (Sp2H) mutant. Development. 1997; 124(2):505-514

6. Takihara $Y$, Tomotsune $D$, Shirai $M$, et al. Targeted disruption of the mouse homologue of the Drosophila polyhomeotic gene leads to altered anteroposterior patterning and neural crest defects. Development. 1997; 124(19):3673-3682.

7. Suniara RK, Jenkinson EJ, Owen JJ. An essential role for thymic mesenchyme in early T cell development. J Exp Med. 2000; 191(6):1051-1056

8. Itoi M, Tsukamoto N, Yoshida H, Amagai T. Mesenchymal cells are required for functional development of thymic epithelial cells. Int Immunol. 2007; 19(8):953964.

9. Jenkinson WE, Rossi SW, Parnell SM, et al. PDGFRalpha-expressing mesenchyme regulates thymus growth and the availability of intrathymic niches. Blood. 2007; 109(3):954-960.

10. Azghadi SM, Suciu M, Gruia AT, et al. Mesenchymal stromal cells support the viability and differentiation of thymocytes through direct contact in autologous cocultures. Histochem Cell Biol. 2016; 146(2):153-165.

11. Jenkinson WE, Jenkinson EJ, Anderson G. Differential requirement for mesenchyme in the proliferation and maturation of thymic epithelial progenitors. J Exp Med. 2003; 198(2):325-332.

12. Rossi SW, Jeker $L T$, Ueno $T$, et al. Keratinocyte growth factor (KGF) enhances postnatal T-cell development via enhancements in proliferation and function of thymic epithelial cells. Blood. 2007; 109(9):3803-3811.

13. Chu YW, Schmitz S, Choudhury B, et al. Exogenous insulin-like growth factor 1 enhances thymopoiesis predominantly through thymic epithelial cell expansion. Blood. 2008; 112(7):2836-2846.

14. Sitnik KM, Kotarsky K, White AJ, et al. Mesenchymal cells regulate retinoic acid receptor-dependent cortical thymic epithelial cell homeostasis. J. Immunol. 2012; 188(10):4801-4809.

15. Lax S, Ross EA, White $A$, et al. CD248 expression on mesenchymal stromal cells is required for post-natal and infectiondependent thymus remodelling and regeneration. FEBS Open Bio. 2012; 2:187-190.

16. Sun L, Sun C, Liang Z, et al. FSP1 (+) fibroblast subpopulation is essential for the maintenance and regeneration of medullary thymic epithelial cells. Sci Rep. 2015; 5:14871.

17. Patenaude J, Perreault C. Thymic Mesenchymal Cells Have a Distinct Transcriptomic Profile. J Immunol. 2016; 196(11):4760-4770.

18. Nikolsky IS, Nikolskaya VV, Taranukha LI, et al. Radiozashhitnoe dejstvie mul'tipotentnyh stromal'nyh kletok timusa [Radioprotective effect of thymus multipotent stromal cells]. Vestnik Ural'skoy meditsinskoy akademicheskoy nauki - Bull Ural Med Acad. 2009; 24(2/1):84-285. [In Russian]

19. Nikolsky IS, Nikolskaya VV, Demchenko DL, Zubov DO. Potentiation of directed osteogenic differentiation of thymic multipotent stromal cells by prior co-cultivation whith thymocytes. Cell and Organ Transplantology. 2016; 4(2):220-223. 
20. Freshney R Ian. Culture of Animal Cells: A Manual of Basic Technique. Wiley Black Well. 2010. $676 \mathrm{p}$.

21. Khaitov RM, Pinegin BV, Yarilin AA. Rukovodstvo po klinicheskoy immunologii. Diagnostika zabolevaniy immunnoy sistemy [Guide to clinical immunology. Diagnosis of diseases of the immune system]. Ruk-vo dlya vrachey - A guide for physicians. M.: GEOTAR-Media, 2009. 345 p.

22. Coligan JE, Kruisbeek AM, Margulies DH, et al. Current protocols in immunology. N.Y.: John Wiley and Sons, 2003. P. 4.1.1-4.1.5.

23. Mossman T. Rapid colorimetric assay for cellular growth and survival application to proliferation and cytotoxicity assay. Methods. 1983; 65(1-2):55-63.

24. Stewart WE. Interferon systems. Vienna/New York: Springer,1979. $421 \mathrm{p}$.

25. Huang M, Yao PW, Chang MD, et al. Identification of anti-inflammatory fractions of Geranium wilfordii using tumor necrosis factor-alpha as a drug target on Herbochip $®$ - an array-based high throughput screening platform. BMC Complement Altern Med. 2015; 15:146.

26. Chumak AA, Kholodna LS. Radiatsiyna imunologiya [Radiation Immunology]. Kyiv: Kyiv Univer., 2001. 89 p. [In Ukrainian]

27. Bifari F, Lisi V, Mimiola E, et al. Immune Modulation by Mesenchymal Stem Cells. Transfus Med Hemother. 2008; 35(3):194-204.

28. Nikolsky IS, Nikolskaya VV, Demchenko DL, et al. Vpliv transplantatsiï mul'tipotentnikh stromal'nikh klitin timusa na imunnu sistemu mishey v umovakh ï regeneratsiï [Effect of transplantation of multipotent stromal cells of thymus on the immune system of mice in conditions of its regeneration]. Fiziologichniy zhurnal. 2018; 64(4):3-11.

29. Wynn RF, Hart CA, Corradi-Perini $C$, et al. A small proportion of mesenchymal stem cells strongly expresses functionally active CXCR4 receptor capable of promoting migration to bone marrow. Blood. 2004; 104(9):2643-2645.

30. Li TS, Shi H, Wang L, Yan C. Effect of Bone Marrow Mesenchymal Stem Cells on Satellite Cell Proliferation and Apoptosis in Immobilization-Induced Muscle Atrophy in Rats. Med Sci Monit. 2016; 22:4651-4660.

31. Li H, Jiang $Y$, Jiang $X$, Guo $X$, Ning H, Li Y, et al. CCR7 guides migration of mesenchymal stem cell to secondary lymphoid organs: a novel approach to separate GvHD from GvL effect. Stem Cells. 2014; 32(7):1890-1903.

32. Li C, Fu Y, Wang Y, et al. Mesenchymal stromal cells ameliorate acute allergic rhinitis in rats. Cell Biochem Funct. 2017; 35(7):420-425

33. Dejbakhsh-Jones S, Jerabek L, Weissman I.L, Strober S. Extrathymic maturation of alpha beta T cells from hemopoietic stem cells. J Immunol. 1995; 155(7):33383344.

34. Barda-Saad M, Rozenszajn LA, Globerson A, et al. Selective adhesion of immature thymocytes to bone marrow stromal cells: relevance to T cell lymphopoiesis. Exp Hematol. 1996; 24(2):386-391.

35. Maria OM, Shalaby M, Syme A, et al. Adipose mesenchymal stromal cells minimize and repair radiation-induced oral mucositis. Cytotherapy. 2016; 18(9):11291145.

36. Li $Y$, Hisha $\mathrm{H}$, Inaba $\mathrm{M}$, et al. Evidence for migration of donor bone marrow stromal cells into recipient thymus after bone marrow transplantation plus bone grafts: a role of stromal cells in positive selection. Exp Hematol. 2000; 28(8):950-960.

37. Wen $S$, Dooner $M$, Cheng $Y$, et al. Mesenchymal stromal cell-derived extracellular vesicles rescue radiation damage to murine marrow hematopoietic cells. Leukemia. 2016; 30(11):2221-2231.

38. Wang Y, Zhu G, Wang J, Chen J. Irradiation alters the differentiation potential of bone marrow mesenchymal stem cells. Mol Med Rep. 2016; 13(1):213-223.

39. Kawase $T, O$ kuda $K$, Nagata $M$, et al. Non-invasive, quantitative assessment of the morphology of $\gamma$-irradiated human mesenchymal stem cells and periosteal cells using digital holographic microscopy. Int J Radiat Biol. 2016; 92(12):796-805.

40. Rühle A, Xia O, Perez RL, et al. The Radiation Resistance of Human Multipotent Mesenchymal Stromal cells Is Independent of Their Tissue of Origin. Int $\mathrm{J}$ Radiat Oncol Biol Phys. 2018; 100(5):1259-1269.

41. Friedenstein Al, Luria EA. Kletochnye osnovy krovetvornogo mikrookruzheniya [Cellular basis of hematopoietic microenvironment]. Moscow: Medicine, 1980.216 p. [In Russian]

42. Nikolsky IS, Nikolskaya VV, Savinova VO. Vliyanie vnutrivennogo vvedeniya mul'tipotentnykh stromal'nykh kletok timusa na immunnyy otvet [Influence of thymic multipotent stromal cells intravenous introduction on immune response]. Vestnik Ural'skoy meditsinskoy akademicheskoy nauki - Bull Ural Med Acad. 2012; 4:55-6. [In Russian]

43. Alcayaga-Miranda F, Cuenca J, Khoury M. Antimicrobial Activity of Mesenchymal Stem Cells: Current Status and New Perspectives of Antimicrobial Peptide-Based Therapies. Front Immunol. 2017; 8:339.

44. Keane C, Jerkic M, Laffey JG. Stem Cell-based Therapies for Sepsis. Anesthesiology. 2017; 127(6):1017-1034.

45. Pachler K, Ketterl N, Desgeorges A, et al. An In Vitro Potency Assay for Monitoring the Immunomodulatory Potential of Stromal Cell-Derived Extracellular Vesicles. Int J Mol Sci. 2017; 18(7):1413.

46. Cheung TS, Dazzi F. Mesenchymal-myeloid interaction in the regulation of immunity. Semin Immunol. 2018; 35:59-68.

47. Mousa HSE, Shalaby SM, Gouda ZA, et al. Efficacy of human umbilical cord derived-mesenchymal stem cells in treatment of rat bone marrow exposed to gamma irradiation. Ann Anat. 2017; 210:64-75.

48. Shim S, Lee SB, Lee JG, et al. Mitigating effects of hUCB-MSCs on the hematopoietic syndrome resulting from total body irradiation. Exp Hematol. 2013; 41(4):346353.

49. Nikolsky IS, Semenova MA, Nikolskaya VV, et al. Sravnitel'naya kharakteristika vliyaniya mul'tipotentnykh stromal'nykh kletok kostnogo mozga na razvitie ostrogo i prolongirovannogo stressa [Comparative characteristics of the influence of multipotent bone marrow stromal cells on the development of acute and prolonged stress]. The materials of the Ist Eurasian Congress «Stem Cell Transplantation». Minsk, 2013. P. 111-113. [In Russian]

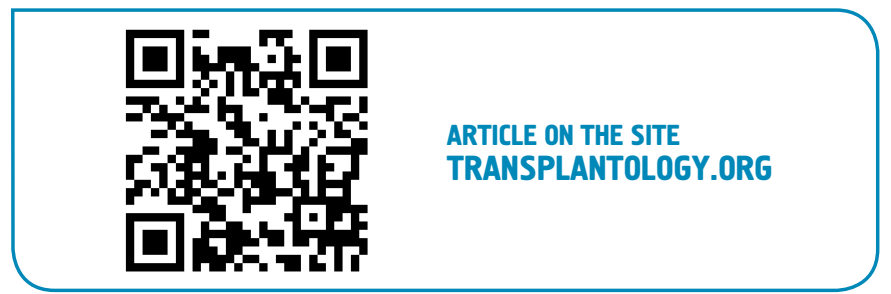

The author indicates no potential conflicts of interest. 